\title{
特定有効細菌の海水中有機物分解機構 と海水浄化への活用法
}

\author{
村上仁士 $^{1} \cdot$ 伊藤禎彦 $^{2} \cdot$ 水口裕之 $^{3} \cdot$ 上月康則 ${ }^{4} \cdot$ 落合道和 ${ }^{5}$ \\ 1フェロー 工博 徳島大学教授 工学部建設工学科（テ770 徳島県徳島市南常三島 2-1） \\ ${ }^{2}$ 正会員 工博 京都大学助教授 大学院工学研究科環境工学専攻 （广606-01 京都府京都市左京区吉田本町） \\ ${ }^{3}$ 正会員 工博 徳島大学教授 工学部建設工学科 （770 徳島県徳島市南常三島 2-1) \\ ${ }^{4}$ 正会員 工博 德島大学講師 工学部建設工学科（干770 徳島県徳島市南常三島 2-1） \\ ${ }^{5}$ 正会員 工修 日建技術コンサルタント（テ578大阪府東大阪市稲葉 2-1-10）
}

\begin{abstract}
海水中有機物の分解に優れた細菌Pseudomonas paucimobilisの分解機構を把握し，その工学的利用性を検討 した.まず，P.paucimobilis には，直接有機物を分解する他に，他の細菌群の有機物分解活性を著しく増強さ せる作用があることがわかった，その機構として，はじめにP.paucimobilis が難分解性の有機物を易分解性に 変換し，ついで自然生育の混合細菌群が分解するものと推定した.この結果，P.paucimobilis は単独で使用す るより，むしろ混合培養系で活用する方が有効であることがわかった．また，P.paucimobilis の沿岸の砂利へ の付着・定着過程，およびその環境水中での生残性について調べた。 さらに，砂利およびコンクリートを担 体として, これにP.paucimobilis を付着させて净化実験を行い, いずれも有機物分解能が高まることを示した.
\end{abstract}

Key Words : coastal seawater,rock bed contact-purification, Pseudomonas paucimobilis,porous concrete

\section{1. 緒言}

生態系の機能を活用した水環境の改善に関する調 查研究が盛んに行われている. 閉鎖性の内湾や海域 のような污濁状態にある海水の水質を直接改善しよ うとする試みにおいても, 主として噝間接触酸化法 に着目した調査研究が行われてきた.

ここで浄化すべき物質は対象海域によって異なる ものの, 一般に, 懸濁物質, 窒素, リン, 有機物な どであり，これらを指標とした浄化作用の評価や装 置の維持方法などの検討が行われてきている.これ までの研究結果からは, 懸濁物質についてはこれを 効率良く除去することは可能であるが，特に溶存態 の有機物に対する除去効果が低い点が特徵であるこ とが明らかになってきた ${ }^{1)-3)}$. ところで, 海水中 有機物は, 本来, 生物分解作用を受け難い有機物で 構成されていると考える必要がある4). 著者らは, AOC (Assimilable Organic Carbon ; 同化可能有機 炭素）指標を用いることにより，海水中の有機物は, 河川水や下水処理水などと比較して生物分解しにく いものの割合が高いことを確認した ${ }^{5)}$.

著者ら ${ }^{6)}$ は, この海水中に存在する生物難分解性
の溶存態有機物に着目し, 磁間接触酸化法の弱点を 補うものとして，これを積極的に分解・除去する方 法を開発しようと試みた。そのためにまず，海水中 の難分解性有機物を効率的に分解しうる細菌として Pseudomonas paucimobilis を見いだした. 沿岸水 中あるいは海岸の砂利や構造物上の付着細菌の中に, P.paucimobilis がどれくらい存在するかについては 明らかではない。しかし，一般にこれらの場におけ る従属栄養細菌のうち Pseudomonas 属は数十\%存 在すると推定される ${ }^{7) ， 8)}$. P.paucimobilis も一般 に存在すると予想され, 現時点では, 本細菌を人工 的に少量添加しても既存生態系に影響しないものと 考えている.

本研究では, このP.paucimobilis の有機物分解機 構を把握した上で，これを実際に利用するための基 礎的な検討を行ったもので, 主たる検討内容は以下 の 3 点である.

第一に, 実際にこの細菌を利用する場を考えると, P.paucimobilis 単独では存在し得ず, 他の細菌や生 物が共存することになる。本研究は，このような自 然の海岸環境を考慮して, この細菌が他の細菌との 共存下で, いかに有機物分解能を発揮するか, また, 
その分解機構について実験的な考察を行った. 第二 に，この細菌を実際に活用する上での課題点につい て検討を行った. すなわち，特定の細菌を用いて分 解を行わせるためには, 細菌をある場所に保持した 上で, 海水がそこを通過するようにする必要がある. ここでは砂利などをP.paucimobilis の担体とし, そ こに付着・定着させうるかについて検討するととも に, 付着した細菌が実際に水環境中で剥離したり, また淘汰されたりすることはないかについて調べた. 第三に, P.paucimobilis が付着した担体のもつ有機 物分解能について調べた.

なお，本研究の一部は既に報告している $\left.{ }^{91} ， 10\right)$ が，本文は，これらに新たな実験的検討を加え，再 構成したものである.

\section{2. 実験方法}

\section{（1）特定細菌と他細菌との共存系における有機物分 解特性に関する実験}

この実験の目的は, 種々の細菌群が共存する自然 環境を考慮し, P.paucimobilis が, 他の細菌との共 存下で, いかに有機物分解能を発揮するか, および その分解機構について調べることである.

\section{a）混合培漛系における有機物分解能}

表一 1 に示す炭素化合物利用性試験培地 ${ }^{1}{ }^{1}$ ) (表一 2 に示す人工海水を成分としている）に，炭素源と して，あらかじめ作製しておいた濃縮海水 ${ }^{9)} \mathrm{TOC}$ 約 $4 \mathrm{mg} \cdot 1^{-1}$ となるように添加した. 混合培養系を 形成する細菌群は, 海岸構造物より採取した付着細 菌を, 上記培地に接種し, 容量 $300 \mathrm{ml}$ の三角フラ スコ中で擋汼条件で培養しておいたものを用いた. 実験に用いる試料水は, 沿岸海水を, 懸濁物質除去 のためグラスファイバーフィルター（アドバンテッ ク GS-25）でろ過し，また，水中に存在する細菌を 不活化させるために, $60 \sim 70^{\circ} \mathrm{C}, 30$ 分間の加熱処 理を行った. 試料水は, DOC $4.5 \mathrm{mg} \cdot 1^{-1}, \mathrm{pH} 8.2$, 実用塩分（または単に塩分） ${ }^{12)} 32$ であった.

分解実験においては, まず容量 $200 \mathrm{ml}$ の三角フラ スコに試料水を $150 \mathrm{ml}$ 入れ，ここに，表一 3 に示す ような細菌の割合となるように, 付着細菌と P.paucimobilis の割合を調整して接種した. 細菌数 は, 沿岸水中の細菌数 ${ }^{13)}$ を考慮して, $10^{4} \mathrm{CFU}$ ・ $\mathrm{ml}^{-1}$ オーダーに調整した. 以下, 表一 3 の実験条件 について説明する. CASE 1, 5 は, それぞれ付着細 菌，P.paucimobilisの夕を $10^{4} \mathrm{CFU} \cdot \mathrm{ml}^{-1}$ に調整 したもの, また, CASE 2, 3 は, それぞれ付着細 菌 $10^{4} \mathrm{CFU} \cdot \mathrm{ml}^{-1}$ に対して, P.paucimobilis を 10 ,
表-1 炭素化合物利用性試験培地の組成

\begin{tabular}{l|l}
\hline $\mathrm{NH}_{4} \mathrm{NO}_{3}$ & $1.0 \mathrm{~g}$ \\
$\mathrm{KH}_{2} \mathrm{PO}_{4}$ & $1.0 \mathrm{~g}$ \\
$\mathrm{MgSO}_{4} \cdot 7 \mathrm{H}_{2} \mathrm{O}$ & $0.5 \mathrm{~g}$ \\
$\mathrm{KCl}$ & $0.2 \mathrm{~g}$ \\
人工海水 & $1000 \mathrm{ml}$ \\
$\mathrm{pH}$ & 7.2 \\
\hline
\end{tabular}

表-2人工海水の組成

\begin{tabular}{l|c}
\hline $\mathrm{NaCl}$ & $23.5 \mathrm{~g}$ \\
$\mathrm{MgCl}_{2}$ & $5.0 \mathrm{~g}$ \\
$\mathrm{Na}_{2} \mathrm{SO}_{4}$ & $3.9 \mathrm{~g}$ \\
$\mathrm{CaCl}_{2}$ & $1.1 \mathrm{~g}$ \\
$\mathrm{KCl}$ & $0.66 \mathrm{~g}$ \\
$\mathrm{NaHCO}_{3}$ & $0.19 \mathrm{~g}$ \\
蒸留水 & $1000 \mathrm{ml}$ \\
\hline
\end{tabular}

表-3 付着細菌と P.paucimobilis の混合割合

\begin{tabular}{c|l}
\hline 実験CASE & 混合割合 \\
\hline CASE1 & 付着細菌のみ \\
CASE2 & 付着細菌+P.paucimobilis (10\%) \\
CASE3 & 付着細菌+P.paucimobilis (100\%) \\
CASE4 & P.paucimobilis +付着細菌 (10\%) \\
CASE5 & P.paucimobilis のみ \\
\hline
\end{tabular}

100\%となるように添加したものである. 逆に, CASE 4 は, P.paucimobilis $10^{4} \mathrm{CFU} \cdot \mathrm{ml}^{-1}$ に対 して, 付着細菌 $10 \%$ となるように細菌数を調整した ものである. 分解は, スターラーで擋汼しつつ, $25^{\circ} \mathrm{C}$, 暗所で行った. 有機物濃度 (DOC) は, 島津製作所 製 TOC-5000 を用いて，1，2 日後に測定した. DOC 3 回測定してその平均を求めたが, 測定試料 は1つである.

\section{b）有機物分解機構に関する実験}

まず, 上で行った実験において, 分解 2 日後の試 料水の AOC (Assimilable Organic Carbon; 同化可 能有機炭素）を測定した ${ }^{5)}$ ，14)。AOC は, 従属栄 盖細菌の増殖から夕た水質の生物学的安定性の尺度 である.すなわち、多種類の有機化合物を低濃度で 利用できる細菌として Pseudomonas fluorescens を用い, その増殖量から, 水中の易分解性有機物の 量を推定するものである.

つぎに, P.paucimobilis と混合細菌群の有機物分 
表-4 高速液体クロマトグラフの分析条件

\begin{tabular}{|c|c|}
\hline テュアルポンプ & 東ソー CCPS \\
\hline 検出器 & 東ソー UV-8020 \\
\hline カラム & $\begin{array}{r}\text { TSK gel G250OPWXL, } \\
7.8 \mathrm{mmID} \times 30 \mathrm{~cm}\end{array}$ \\
\hline 排除分子量限界 & $5000 \mathrm{D}$ \\
\hline 空嘹体㮴 $\left(V_{0}\right)$ & $5.0 \mathrm{ml}$ \\
\hline 押し出し液 & $0.02 \mathrm{M}$ リン酸緩街液, $\mathrm{pH} 6.9$ \\
\hline 流量 & $0.8 \mathrm{ml}$ \\
\hline 試料注入量 & $100 \mu l$ \\
\hline 温度 & $25^{\circ} \mathrm{C}$ \\
\hline
\end{tabular}

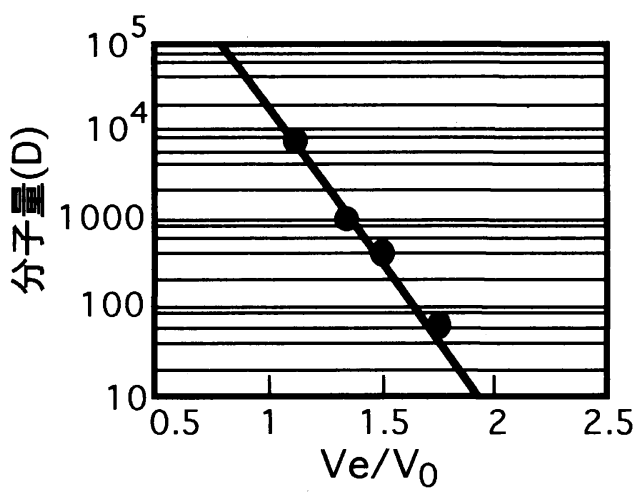

図-1 クロマトグラフの押出位置と分子量の関係

解過程を区別するため，それらの分解順序を変える 以下の実験を行った. $300 \mathrm{ml}$ 三角フラスコに，グラ スファイバーフィルター（アドバンテック GS-25) でろ過した海水 (DOC $4.2 \mathrm{mg} \cdot \mathrm{l}^{-1}$, p H 7.6, 実用 塩分 25） $300 \mathrm{ml}$ を入れ，これに P.paucimobilis ま たは自然生育の混合細菌群を，それぞれ $1.5 \times 10^{3}$ $\mathrm{CFU} \cdot \mathrm{ml}^{-1}$ となるように入れた。これをスターラ 一で擋汼しつつ, $25^{\circ} \mathrm{C}$, 暗所で培養した. 24 時間経 過した後, 試料全体を $0.45 \mu \mathrm{m}$ メンブランフィル ターでろ過して細菌を除去し, 今度は逆に, P.paucimobilis を添加して培養していた試料には混 合細菌群を添加し, 混合細菌群を添加して培養して いた試料にはP.paucimobilis を添加した.さらに 24 時間培養を行い，DOC 濃度の変化を測定した。

さらに, P.paucimobilis による有機物分解の前後 で 有機物の分子量がいかに変化しているかを高速 液体クロマトグラフを用いて測定した．表一 4 に分 析条件を示す. 流出水中の有機物の分子量は, まず, ポリエチレングリコールの分子量とその流出位置と の関係を求め, これを用いて測定した。ポリエチレ ングリコール(7500，1000，400D)とエチレングリ コール(62D)を, 示差屈折計で検出し，それらの流 出位置と分子量との関係を図ー 1 のように得た。横
軸は, 流出液量 $(\mathrm{Ve}) /$ / 空隙体積 $\left(\mathrm{V}_{0}\right)$ を示してい る.この直線関係を用いて，つぎの濃縮海水中有機 物の分子量分布を測定した.

この実験における濃縮海水中の有機物の濃度は約 $500 \mathrm{mg} \cdot 1^{-1}$ で, 表ー 1 に示す無機培地に入れた。こ れに, P.paucimobilis を $10^{8} \mathrm{CFU} \cdot \mathrm{ml}^{-1}$ を加え, $25^{\circ} \mathrm{C}$, 暗所で, 1 日分解を行わせた. 分解後, 0.45 $\mu \mathrm{m}$ メンブランフィルターでろ過し，ろ液を分析試 料とした. 流出液の有機物濃度は, $260 \mathrm{~nm}$ の吸光度 によって測定したが，同時に流出液を分画し，DOC 濃度も測定した．有機物濃度が高濃度であるのは高 速液体クロマトグラフで測定可能とするためである が，分解特性に及ぼす影響は明らかではなく，本実 験の結果からは実際の分解機構を推定できるにとど まる.

\section{（2）有効細菌の担体付着と生残性に関する検討}

この実験の目的は，実際に特定有効細菌を活用す るために必要となる検討を行うことである。すなわ ち, P.paucimobilis が担体に付着・定着させること ができるか，また水環境中における生残性について 調べる.

\section{a) 担体付着特性}

実験装置は, 图一 2 に示した接触酸化模型水路 (幅 $100 \mathrm{~mm} \times$ 長さ $500 \mathrm{~mm} \times$ 水深 $80 \mathrm{~mm})$ を用いた.こ の中に, 徳島県小松海岸沿岸で採取した砂利（粒径 $10 \mathrm{~mm}$ 程度）を敷き詰めた。これにはすでに微生物 群が付着しているものとみなした。 空隙率は $45 \%$ で あった.この水路にグラスファイバーフィルター(ア ドバンテック GS-25）でろ過した海水 3.51 を循環 させ，滞留時間は 4 時間（断面平均流速 $0.125 \mathrm{~m} \cdot \mathrm{hr}$ -1) とした.このとき海水が水路内を均等に流れるよ うに, 上流側の整流板には，縦横均等に穴をあけて ある（直径 $7 \mathrm{~mm}, 20$ 個）。ここに P.paucimobilis を約 $10{ }^{4} \mathrm{CFU} \cdot \mathrm{ml}^{-1}$ となるように注入して，これ が砂利に付着, 定着するかを調べた. 実験は暗条件, 水温 $20^{\circ} \mathrm{C}$ で行った．実験条件をまとめて表一 5 に示 す.

細菌数は, Anderson 培地を用い, 平板培養法で測 定した。.また，砂利に付着している細菌数は，取り 出した砂利に蒸留水を注ぎながらブラッシングして 付着物を洗い落とし, この中の細菌数を測定して求 めた。

一方, 本研究では混合細菌中の P.paucimobilis 数 だけを測定あるいは推定する技術が必要である．混 合細菌中の特定細菌だけを測定するためには, 免疫 学的方法や遺伝子工学を応用した方法がすでに開発 


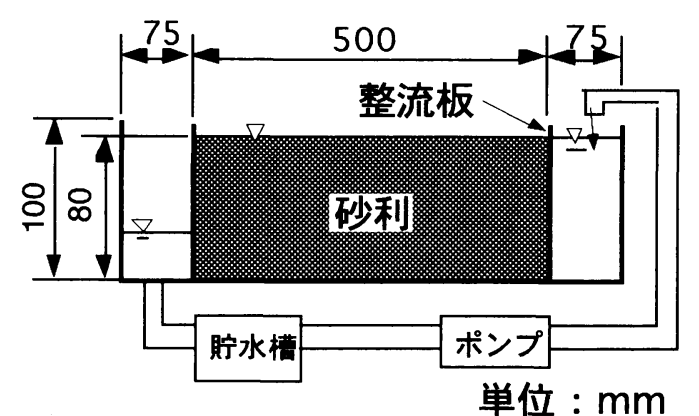

図-2実験用模型水路

表-5 付着実験条件

\begin{tabular}{l|l}
\hline 試料海水量 & 3.51 \\
$\mathrm{pH}$ & 8.3 \\
実用塩分 & 32.0 \\
DOC & $3.2 \mathrm{mg} \cdot \mathrm{I}^{-1}$ \\
㴆留時間 & 4 時間 \\
$\quad$ 断面平均流速 & $0.125 \mathrm{~m} \cdot \mathrm{hr}^{-1}$ \\
水温 & $20^{\circ} \mathrm{C}$ \\
砂利粒径 & $10 \mathrm{~mm}$ \\
水路内砂利空隙率 & $45 \%$ \\
\hline
\end{tabular}

されているが，ここでは以下のような近似法を検討 した．すなわち，表一 1 の炭素化合物利用試験培地 に, 濃縮海水を濃度を変えて与え, 寒天培地におい て形成するコロニー数との関係を調べた. その結果, TOC で $30 \mathrm{mg} ・ 1^{-1}$ の濃縮海水を含む寒天培地では, P.paucimobilis 数にほぼ相当する数の細菌がこの濃 度の有機物に対して耐性を持ち，有機物を利用して 増殖し，コロニーを形成するものと考えられた ${ }^{10)}$. この検討の結果, 混合細菌中の P.paucimobilis 数は, 炭素化合物利用試験培地に濃縮海水を T O C が $30 \mathrm{mg} \cdot 1^{-1}$ となるように添加した寒天培地を用い, この培地上で生育したコロニーを計数することによ って近似的に測定した。

\section{b ) 生残性}

ここでは，上で作製した P.paucimobilis 付着砂利 を実際の沿岸水に対して利用した場合， P.paucimobilis がどの程度生残するかについて調べ る.

徳島県小松海岸に設置されている離岸堤消波ブロ ックの間隙中に浸漬することとした.ここには波浪, 沿岸流, 潮汐流があり, P.paucimobilis 付着砂利を 実際に利用することが想定できる場である.

a) で作製した砂利を，円筒形の金網（直径 $200 \mathrm{~mm}$, 高さ $200 \mathrm{~mm}$ ，穴の大きさ $7 \mathrm{~mm} \times 7 \mathrm{~mm} ）$ に入れ，
表-6 浄化実験の条件

\begin{tabular}{c|l}
\hline CASE 1 & $\begin{array}{l}\text { 現地砂利 } \\
\text { 帯留時間 4 時間 } \\
\text { (断面平均流速0.125m } \cdot \mathrm{hr}^{-1} \text { ) }\end{array}$ \\
\hline CASE 2 & $\begin{array}{l}\text { 現地砂利 }+ \text { P.paucimobilis } \\
\text { 㴆留時間 4 時間 } \\
\text { (断面平均流速0.125m } \cdot \mathrm{hr}^{-1} \text { ) }\end{array}$ \\
\hline CASE 3 & $\begin{array}{l}\text { 現地砂利 }+ \text { P.paucimobilis } \\
\text { 㴆留時間 2 時間 } \\
\text { (断面平均流速0.250m } \cdot \mathrm{hr}^{-1} \text { ) }\end{array}$ \\
\hline
\end{tabular}

ふたをし，消波ブロックの間隙中に浸漬した．浸漬 開始は 12 月で，期間中の水温は $7 \sim 12^{\circ} \mathrm{C}$ ，また， p H 8.2〜8.7，実用塩分 35〜37 であった．浸漬し てから 14，30，90 日後に引き上げて，砂利表面に 付着している細菌数, およびP.paucimobilis 数を測 定した.

\section{（3）細菌付着担体を用いた浄化実験}

この実験の目的は，P.paucimobilis を付着させた 担体のもつ浄化能について検証することである．担 体としては砂利およびコンクリートをとりあげる.

\section{a ）砂利の場合}

実験装置は図一 2 と同じものを用い，付着実験終 了後，水路内の海水を交換して実験を行った. 試料 海水はグラスファイバーフィルター（アドバテック GS-25）でろ過し，懸濁物質を除去したものを用い た.この試料水の DOC は $8.0 \mathrm{mg} \cdot 1^{-1}, \mathrm{pH} 8.0$, 実 用塩分 32 であった. また, 実験条件を表一 6 にまと めて示す. CASE 1 で用いた砂利は, 小松海岸から 粒径 $10 \mathrm{~mm}$ 程度のものを採取したものであり（現地 砂利）, CASE 2，3は付着実験で用いた砂利（混 合細菌とP.paucimobilis が付着している) を用いた. 本実験では浄化効果がいかに発揮されるかを調べる のが第一の目的であるため，滞留時間はまず，（2） a) の実験と同じ 4 時間(CASE 1, 2) とし, CASE 3 はその $1 / 2$ の 2 時間とした.

\section{b ）コンクリートの場合}

実験に用いるコンクリート担体は, 徳島県小松島 港内に設置している海水浄化実験プラント ${ }^{15)}$ に充 填しているテストピースである．普通コンクリート とポーラスコンクリートのテストピースを浸漬して いるが, ともに, 直径 $150 \mathrm{~mm}$, 長さ $300 \mathrm{~mm}$ の円 柱形である. ポーラスコンクリートの条件は, 連続 空隙を持ち, 骨材粒径が 5 20 $\mathrm{mm}$ で空隙率が約 $25 \%$ である. 海水中に浸漬して約 2 ヶ月後のテスト 
ピースを引き上げ, 実験室に持ち帰り, まず, 付着 しているSS とVSS の測定を行った. ポーラスコン クリートに付着しているSS とVSS の測定のために は，テストピースを島津製作所製 $1000 \mathrm{kN}$ 万能試験 機により圧縮破壊し，ハンマーによって砕いた後， ブラッシングして付着物を落としたものを測定試料 とした.

净化実験に際しては，テストピースを図ー 2 に示 すのと同じ形の模型水路内においた．ただし，テス トピースがちょうど浸漬するように, 水深は $150 \mathrm{~mm}$, 海水がコンクリートと接触する部分の長さは $300 \mathrm{~mm}$ としている. この水路に, グラスファイバ ーフィルター（アドバンテック GS-25）でろ過した 海水 71 を循環させ, 暗所, $20^{\circ} \mathrm{C}$ の条件で有機物分 解を行わせた．この試料水の DOC は $5.0 \mathrm{mg} \cdot \mathrm{l}^{-1}$, pH8.0, 実用塩分 30 であった. なお, 循環海水の流 量は $2 \mathrm{l} \cdot \mathrm{hr}^{-1}$ としたが，これは大潮時と小潮時にこ の実験プラントに流入する流量の間にあり，小潮時 の流量の約 2 倍に相当する.

普通コンクリートとポーラスコンクリートに，さ らにP.paucimobilis を付着させて有機物分解を行わ せた.P.paucimobilis の付着方法は，（2）a）に 示した方法と同様である。すなわち，模型水路内で 循環している海水中にP.paucimobilisを注入した. このときの水路内の滞留時間は 2.5 時間であり, 48 時間循環させて付着させた。净化実験は, この循環 させた海水を抜き，新たな海水を注入して行った.

\section{3. 実験結果と考察}

\section{（1）特定細菌と他細菌との共存系における有機物 分解特性}

\section{a ）混合培養系における有樴物分解能}

付着細菌と P.paucimobilis の共存する割合を変 えて有機物分解を行わせた実験結果を図ー 3 に示す. CASE 1〜 5 の条件は表ー 3 に示したものである. 試料水之処理水の DOC を表一 7 に示す. 分解後 2 日 後の值を示してある. 図一 3 において，付着細菌の みを接種した CASE 1 では，有機物除去率は低いの と比較して，P.paucimobilis をそれぞれ 10，100\% 接種した CASE 2,3 は高い除去率が得られている. これに対して，P.paucimobilisのみのCASE 5,お よび付着細菌を $10 \%$ 接種した CASE 4 では，いずれ も有機物の分解活性は低いことがわかる. CASE 1, 4，5 の除去率は，それぞれ 20，23，26\%と，低 い除去率にとどまっているのに対して，CASE 2， 3 は，53，57\%と高い除去率であることがわかる.

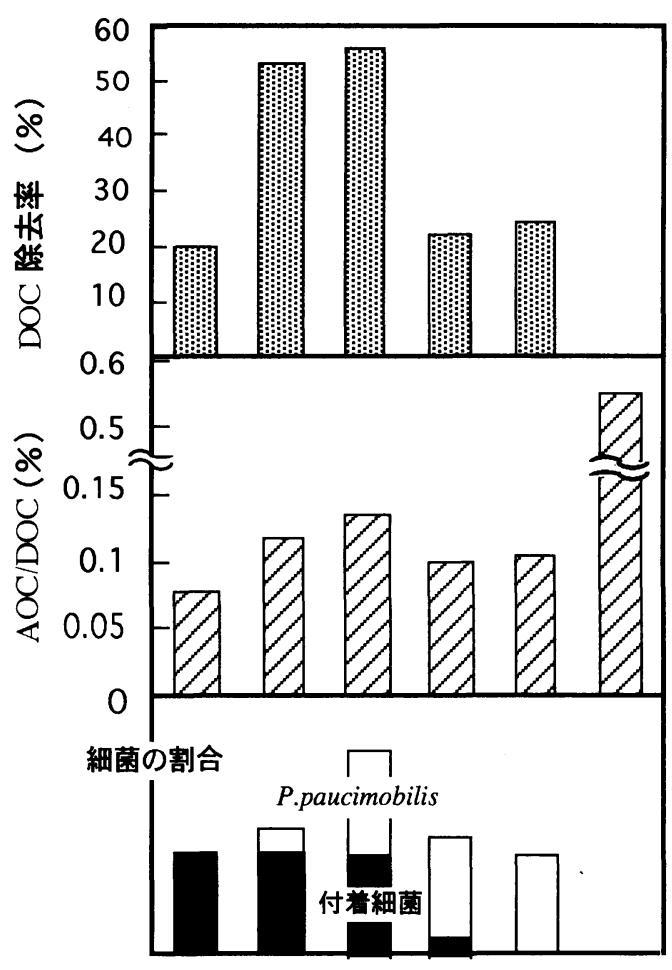

CASE1 CASE2 CASE3 CASE4 CASE5 試料水

図-3 細菌の混合割合と処理水の A O C, D O C

表一 7 混合培盖系における有機物分解特性実験結果

\begin{tabular}{c|cc}
\hline 実検CASE & 処理水DOC $\left(\mathrm{mg} \cdot \mathrm{I}^{-1}\right)$ & 処理水AOC $\left(\mu \mathrm{g} \cdot \mathrm{I}^{-1}\right.$ \\
\hline CASE1 & 3.60 & 2.7 \\
CASE2 & 2.12 & 2.5 \\
CASE3 & 1.95 & 2.6 \\
CASE4 & 3.52 & 3.5 \\
CASE5 & 3.42 & 3.5 \\
試料水 & 4.50 & 24.8 \\
\hline
\end{tabular}

以上の結果，P.paucimobilis には，有機物の分解 に直接関与する他に, 他の細菌と共同して, 混合系 全体の細菌群の有機物分解活性を促進, 增強する働 きをもつことが明らかとなった，本実験結果は，自 然に増殖した細菌群に対し, 細菌数の割合として 10 〜 100\%のP.paucimobilis を添加することで, 有機 物の除去率を $2 \sim 3$ 倍に増大させることが可能であ ることを示している.

\section{b ）有機物分解機椿}

図ー3に示された共生分解の機構について検討す るためさらに検討を行った.

$\mathrm{AOC}$ の測定結果を表ー 7 に示し, $\mathrm{AOC} / \mathrm{DOC}$ の値 


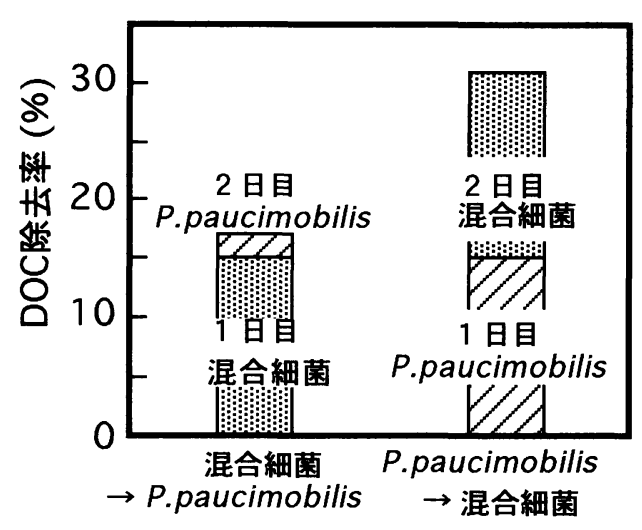

図-4 P.paucimobilis および混合細菌の有機物分解特性

を図ー 3 中に示した. AOC 指標の意義からみて, $\mathrm{AOC} / \mathrm{DOC}$ の值は水中の有機物の生物学的安定性の 一つの指標と考えることができる ${ }^{16)}$. CASE 2 およ び 3 のAOC/DOCが, CASE 1 の場合の值よりも大 きいことがわかる. CASE 1 で AOC/DOC 值が小さ くなったのは, 自然の細菌群によって易分解性の有 機物が多く分解されたためであると思われる.一方, CASE 2，3の場合は, P.paucimobilis と自然細菌 群が共存しているが, P.paucimobilis が難分解性有 機物を易分解性有機物に変換した結果, 分解後の水 においても, AOC/DOC 值が大きくなったものと推 察できる.

図一 3 を得た実験は, P.paucimobilis と付着物中 の混合細菌群が共存する条件である.つぎにこれら の有機物分解過程を区別するため, 細菌の分解順序 を変えて有機物分解を行わせた. 結果を図ー4に示 す. 1 日後 (24 時間後) は, P.paucimobilis と混合 細菌群を添加したものの両者の間にほとんど差は認 められない. しかし, 添加する細菌群を変えて培養 を行った 2 日後（48 時間後）には, 除去率に著しい 差が認められた.すなわち，1 日目混合細菌群 $\rightarrow 2$ 日目 P.paucimobilis としたものでは，2 日目に P.paucimobilis が除去した有機物量は極めて少ない のに対して，1日目P.paucimobilis $\rightarrow 2$ 日目混合細 菌群としたものでは, 2 日目に混合細菌群は有機物 を効率よく分解している.

前者の場合, まず1日目に混合細菌群が易分解性 の有機物を分解, 無機化した結果, 難分解性有機物 だけが残存する状態となる.ついで 2 日目において はP.paucimobilis は, 残存する難分解性有機物を易 分解性有機物に変換していると推定されるものの, 無機化までには至らず, DOC 除去率は増大していな いと考えられる. 一方, 後者の場合, 1 日目に

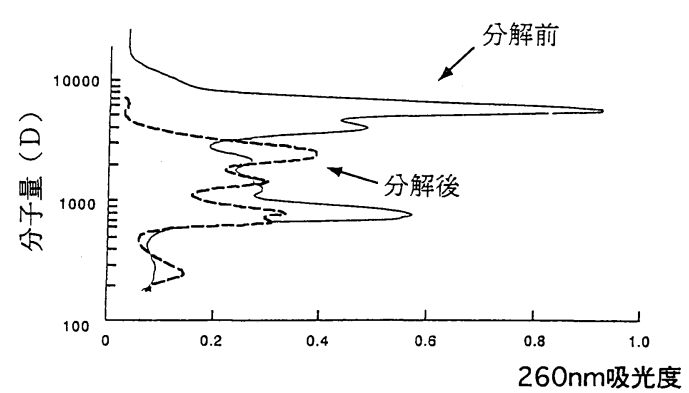

図-5 P.paucimobilisによる分解にともなう有機 物の分子量変化

P.paucimobilis は，易分解性の有機物を分解，無機 化する一方, 難分解性有機物を易分解性のものに変 換していることが考えられる．このため，2日目に 混合細菌群を添加して培養を行ったとき，これらの 易分解性有機物を分解, 無機化できたものと考えら れる。これらの有“機物分解過程を区別せず, P.paucimobilis と混合細菌群が同時に分解を行った 場合の結果が図ー 3 に示されている. 図一 4 の結果 とあわせて考えると, 混合培養系である CASE 2 ,

3 で除去率が高く, かつ処理水の AOC/DOC の值が 大きいのは, まず P.paucimobilis が難分解性の有 機物を易分解性に変換し, ついで自然生育の混合細 菌群が分解, 無機化した結果であると推定すること ができよう。

図一 5 に, P.paucimobilis による分解の前後での 分子量の分布を示す. 縦軸は, 図一 1 を用いて決定 した分子量を示している. 分子量 6000 と 800 にピ 一クをもつ有機物が減少し, 分子量 2500 と 250 付 近にピークをもつ有機物が増大していることがわか る. この結果は, P.paucimobilis が, 難分解性であ ると思われる高分子量の有機物を, より低分子の有 機物に変換していることを示している.

P.paucimobilis による分解の前後での, 濃縮海水 を分画した流出液中の DOC を測定した結果を図一 6 に示す. 図一 5 においては, 6000 にピークをもつ 有機物はなくなっているものの, 図一6では, DOC として測定され，有機物としては残存していること がわかる. $260 \mathrm{~nm}$ を吸収する有機物は, 主として不 飽和結合をもつ化合物である.したがって, これら の結果は, P.paucimobilis は高分子の有機物の一部 を低分子のものに変えているの夕ならず，有機物の 分子構造を変えていることを示唆している. Ogura ${ }^{17)}$ は, 海水の表層水の微生物分解性を調べ, 低分子（500以下）の有機物は速く分解が進むため, その後には高分子有機物の割合が高くなる傾向であ 


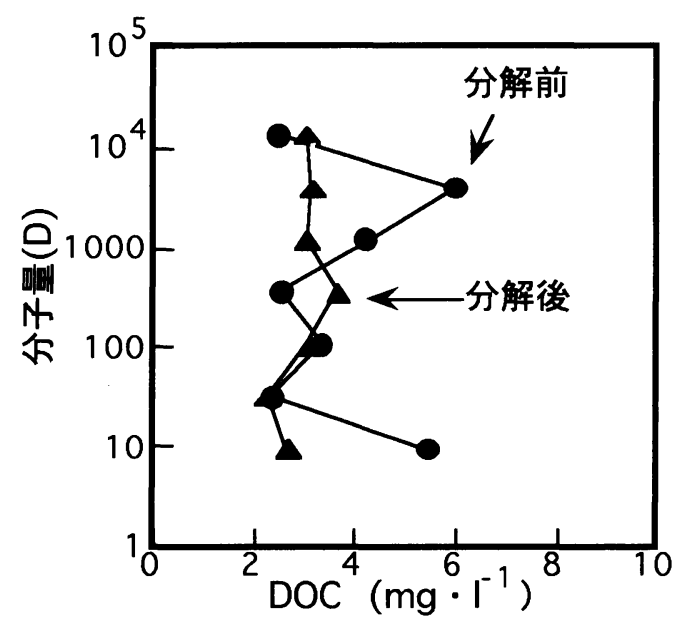

図-6 P.paucimobilis による分解前後における 分画流出水のDOC

ると報告している.これは, 本研究においては通常 の細菌群が低分子の易分解性の有機物を分解する場 合に相当すると考えられる.

以上 3 つの実験から，P.paucimobilis と混合細菌 群との共生分解の機構をまとめると, (1) P.paucimobilis は，難分解性の有機物を易分解性の ものに変換し，これを他の細菌群が利用する. (2)そ の過程では，P.paucimobilis は，高分子の有機物を 低分子に変換したり，有機物の構造を変えているこ とが考えられる。これらが，有機物分解における P.paucimobilis の具体的な役割であると考えること ができる.

\section{（2）有効細菌の担体付着と生残性}

つぎに, 以上の特性を有する特定有効細菌を工学 的に活用するために必要な検討を行った. すなわち, P.paucimobilis が担体に付着・定着しうるか，また 水環境中における生残性について調べた.

\section{a) 担体付着特性}

結果を図ー 7 に示す. 浮遊細菌数は $\mathrm{CFU} \cdot \mathrm{ml}^{-1}$, 付着細菌数は砂利表面に対する $\mathrm{CFU} \cdot \mathrm{cm}^{-2}$ で表し てある. ○付着 P.paucimobilis とは○付着細菌の中 のP.paucimobilis の数を表している. ただし，この P.paucimobilis 数は, 実験方法（2）a）に示した 近似法によって測定したものである. 海水を流し始 めて 3 時間で, 付着細菌数が急激に増加しているこ とから，P.paucimobilis も初期に付着しうるものと 考えられる. また, その後も, 水中の浮遊細菌が減 少する一方, P.paucimobilis を含む付着細菌数が緩 やかに増大しており，付着は継続していることがわ かる. 図一 7 における浮遊細菌数, 付着細菌数,

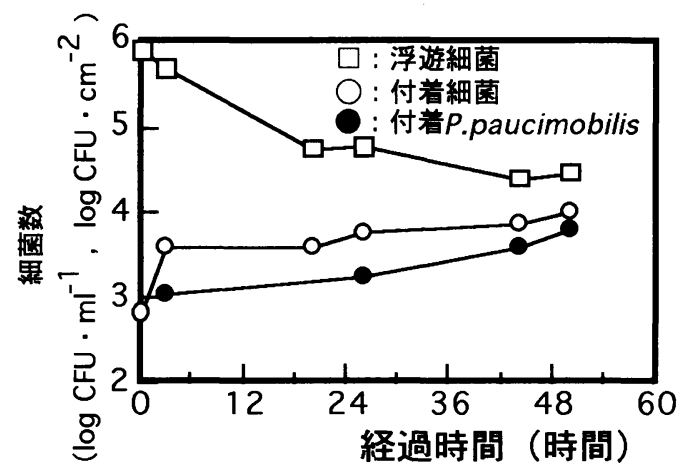

図-7 P.paucimobilis の砂利への付着

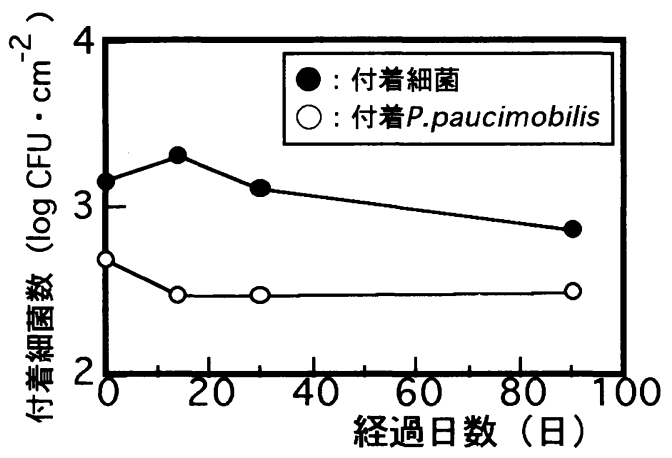

図-8 環境水中における砂利付着細菌の生残性

P.paucimobilis 数はいずれも増殖を含んだものであ るが, 浮遊細菌の数が大きく減少していることから， 付着過程が卓越しているものと考えられる.

また，付着細菌の構成比をみると，この実験条件 では，P.paucimobilis 以外の混合細菌に対する P.paucimobilis の割合は20〜70\%の範囲であった. これは図ー3で示した，P.paucimobilis が有効に働 きうる 10〜 100\%の範囲内にあり，P.paucimobilis を付着させて新たにつくった砂利は, 高い有機物除 去能力を有することが期待できる.

この, P.paucimobilis を付着させた砂利の有機物 分解活性は（3）で調べている.

\section{b ) 生残性}

結果を図ー8に示す.P.paucimobilisが 14 日後ま でのあいだにやや減少しているようである．砂利表 面に弱く付着していたP.paucimobilisが脱離したも のと推察される.しかし, 減り続けるということは なく, その後は安定している. すなわち, この検討 からは, P.paucimobilis だけが剥離したり淘汰され たりする様子はみられず, 他の細菌と同様, 定着し ているものと考えられた。混合細菌数 (P.paucimobilis 除く) に対するP.paucimobilis の 割合は, 約 20〜50\%の範囲であり, P.paucimobilis が有効に㗢く範囲を維持していた. 


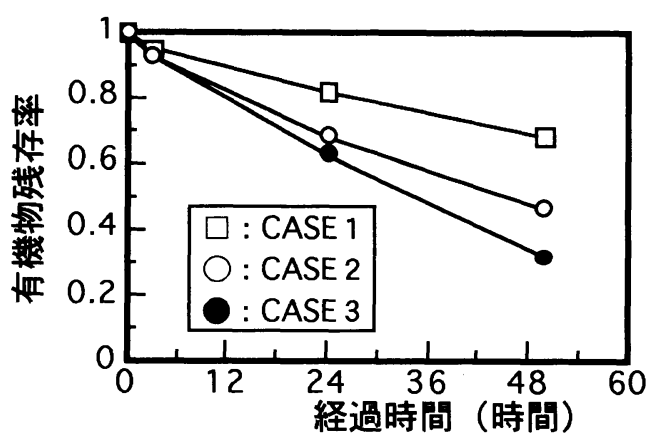

図-9 有機物濃度の経時変化

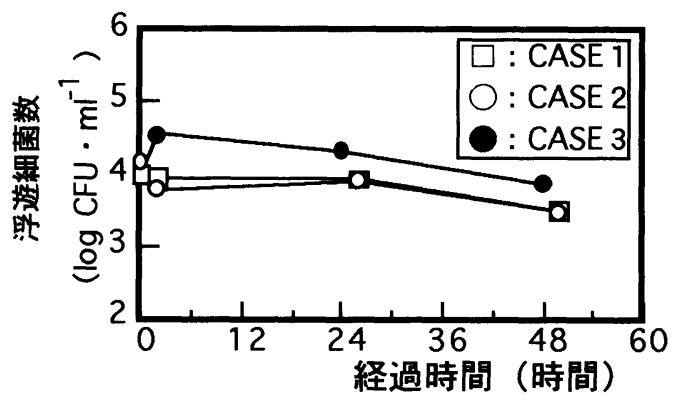

図-10 浮遊細菌数

図一 7，8の結果，P.paucimobilis は担体として の砂利上に付着させることができ，これを実際に水 環境中で利用したときも付着状態をある程度保てる ことがわかった. また，このときのP.paucimobilis 以外の混合細菌に対するP.paucimobilisの割合も, P.paucimobilis が有効に㗢きうる範囲内であった.

\section{（3）細菌付著担体の浄化能}

これまでに，P.paucimobilis の基本的な有機物分 解特性，および砂利担体に対する付着と生残性につ いて検討した．ここでは，P.paucimobilisを付着さ せた担体のもつ浄化能について検討を行った。担体 としては砂利およびコンクリートをとりあげている.

\section{a）砂利の場合}

有機物濃度を経時的に測定した結果を図ー9に示 す. 各実験ケースの条件は表一6に示した通りであ る。まず，滞留時間が 4 時間のケースで， P.paucimobilis が付着している CASE 2 と付着して いないCASE 1 を比較すると, 50 時間後の DOC の 除去率は, CASE 1 で $32 \%$, CASE 2 は $53 \%$ となっ ている. 担体に P.paucimobilis が付着している CASE 2 は CASE 1 に比べ 1.7 倍の分解能を有して いた.このように自然に生育した細菌群が付着して いる担体にP.paucimobilis を加えることにより，実 際に有機物の除去効果が高まることがわかった.

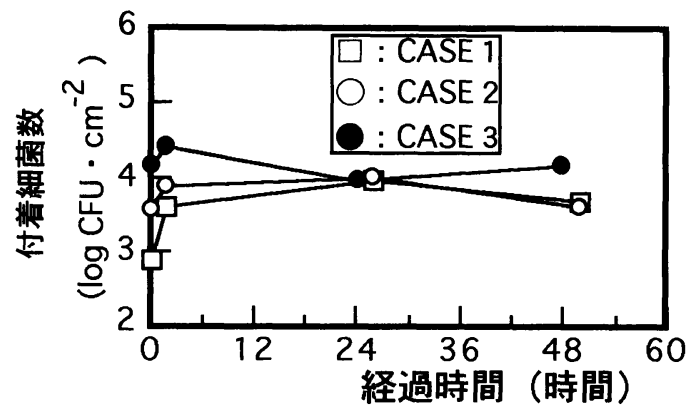

図-11 付着細菌数

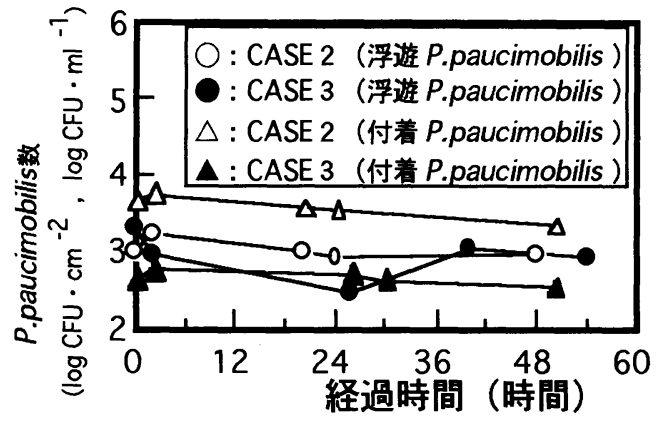

図-12 P.paucimobilis 数

また, 滞留時間が 4 時間(CASE 2) と 2 時間(CASE 3 )のケースの除去率はそれぞれ 53，68\%であり， CASE 2 より CASE 3 の方が除去率が高いことがわ かる.これは，流速の大きい方が，砂利表面の境膜 が薄くなる結果, 砂利表面の細菌への物質の供給が 効率よく行われるためであると考えられる．この場 合，比較的遅い流速で実験を行ったためにこのよう な結果になったが，実際の海域における流速の範囲 でもこのようなことがおきうるかについては別途検 討が必要である.

水路内の細菌数を測定した結果を図ー10〜12 に 示す. 図一10は，浮遊している全体の細菌数であり， 図一11 は，砂利に付着した全体の細菌数，また，図 -12 は, P.paucimobilis 数を示している. 全体に大 きな細菌数の変化はない. 図一10より, 浮遊細菌数 がやや減少傾向にあるのに対して，図一11 より，付 着細菌数がやや増加あるいは一定数を保っている.

すなわち，細菌は担体上に定着しつつ，有機物を分 解していると推察できる，さらに，図一13に，循環 させている海水 3.51 に含まれる細菌数と, 砂利に付 着した細菌数を，CASE 2 において比較したものを 示す.この図より，水路内の細菌は砂利に付着して いる細菌数の方がはるかに大きく，この実験で浮遊 細菌による有機物除去の影響は少ないと考えられる。 CASE 3 についても同様であった. 


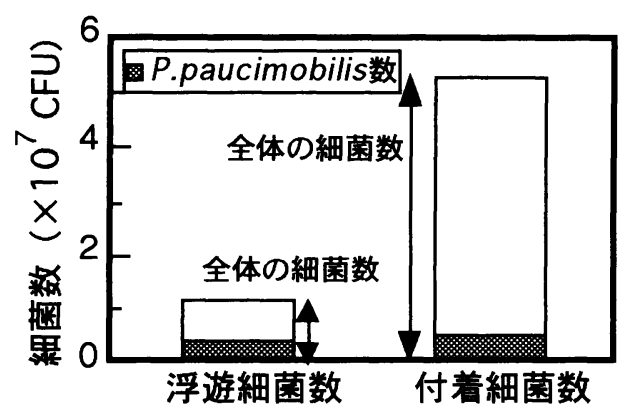

図-13 水槽内細菌数（CASE2）

また，DO，pH も同時に測定した. $\mathrm{pH}$ は全ての ケースにおいて 8.0 前後で一定であった. 実験開始 時の DOは $9.2 \mathrm{mg} \cdot 1^{-1}$ であり, 50 時間後には CASE 1 が $6.4 \mathrm{mg} \cdot 1^{-1}$, CASE 2 が $5.3 \mathrm{mg} \cdot 1^{-1}$ と低下した が, CASE 3 ではほとんど変化がなかった．有機物 除去率が大きい方が DO 低下も大きいといえるが, CASE 3 では CASE 1，2 に比べて流速が大きいた め再曝気の効果が大きく, DO 変化がみられなかっ たと考えられた. また，本実験ではDO の低下によ る細菌活性への影響はないものと考えられた。

\section{b ) コンクリートの場合}

分解実験を行った結果を図ー14に示す. 実験中の DO, $\mathrm{pH}$ に大きな変化はなかった. また，この間の 浮遊細菌数, 付着細菌数, P.paucimobilis は砂利担 体の場合に示した図一10，11，12 と同様の傾向を 示した $^{18)}$. また，付着していた SS とVSS の測定 結果を, 単位体積あたりとして表示したものを図一 15 に示す. 図一14から，まず，P.paucimobilis が 付着していない場合を比較すると, ポーラスコンク リートの方が普通コンクリートと比較して浄化能が 高く, 約 2.2 倍の除去率となっている. 図一15に示 したように, ポーラスコンクリートは普通コンクリ 一トに比べて, 多くのSS とVSS を保持することが でき, ポーラスコンクリートの方が微生物分解が活 発であるといえる.

図ー14 から，普通コンクリートとポーラスコン クリートともに, P.paucimobilis を付着させるとよ り多くの有機物が分解されていることがわかる. P.paucimobilis を付着させれば，その除去率は，普 通コンクリートの場合で約 1.6 倍, ポーラスコンク リートで約 1.4 倍となっている. 以上まとめれば, この実験の場合, 普通コンクリートに対してポーラ スコンクリートを用いれば, 浄化能は 2.2 倍となり, それにP.paucimobilisを付着させて用いればさらに 1.4 倍の浄化能が得られたことになる.

ここで P.paucimobilisの添加効果についてまとめ

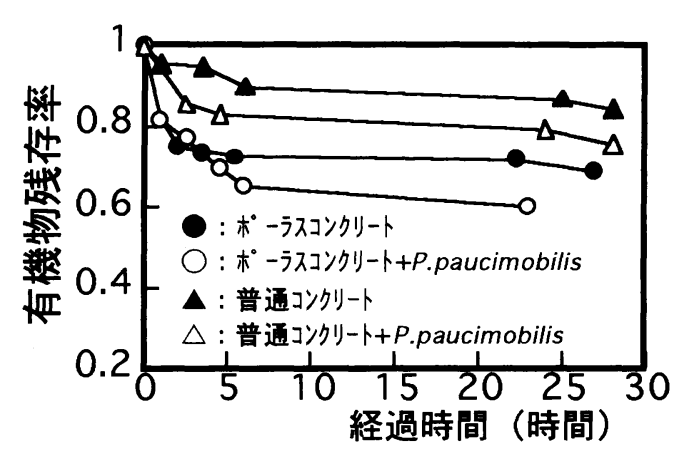

図-14コンクリート担体による有機物分解

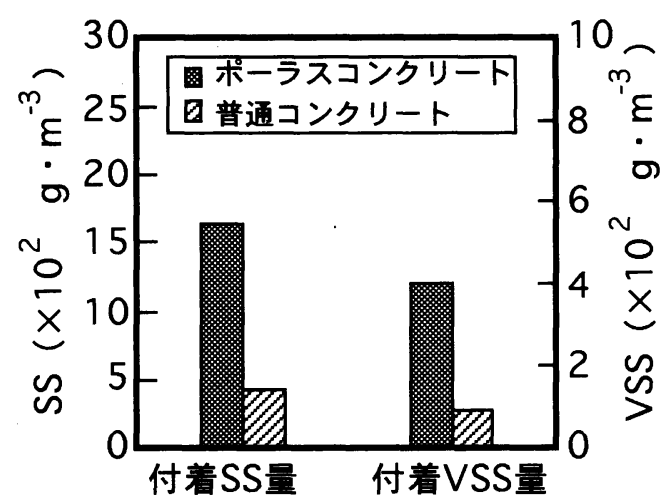

図-15 コンクリート担体に付着したSS, VSS (浸漬 2 ケ月後)

てみると，図一 3では $2 \sim 3$ 倍の有機物除去率が得 られたのに対して、砂利担体を用いた図一 9 では 1.7 倍, コンクリート担体を用いた図ー14では 1.6 倍, 1.4 倍亡やや低下している傾向がある.図ー 3 では三 角フラスコで擋拌条件で分解を行わせているのに対 して，図一9，14では細菌が付着した条件であると いう違いとも考えられるが詳細は不明である.

図ー15 に示した付着 SS 量, 付着 VSS 量は浸漬 2 カ月後の瞬間値であり, 単位 SS またはVSS あたり の除去能について評価することは難しい，夏季にお ける累積の有機物除去能力を別途試算したところ， 海水浄化実験プラントの単位幅当たり，ポーラスコ ンクリートで $5.6 \mathrm{~g} \cdot \mathrm{m}^{-1} \cdot \mathrm{day}^{-1}$ (溶存態 $2.9+$ 懸濁態 2.7），普通コンクリートで $3.5 \mathrm{~g} \cdot \mathrm{m}^{-1} \cdot \mathrm{day}^{-1}$ （溶 存態 1.4+懸濁態 2.1）であった．これを砂浜の汀線 $1 \mathrm{~m}$ あたりの除去速度と比較すると,ポーラスコンク リートの場合で砂浜の 15 26\%程度であると評価 できた ${ }^{15)}$. この净化能力に対する P.paucimobilis を利用したときの効果を検討することがつぎの課題 となる．本実験で P.paucimobilis を付着させたコン クリート担体を実際に海水净化に利用し，短期的に はここで得られたのと同等の浄化効果があることを 
認めた ${ }^{15)}$ が，その持続性等については今後の課題 となっている.

\section{4. 結言}

本研究で得られた成果を要約する.

（1）混合培養系におけるP.paucimobilis の有機物 分解特性を調べた結果, P.paucimobilis には, 直接 有機物を分解する他に, 他の細菌群の有機物分解活 性を著しく増強させる作用があることがわかった。 その機構として，まず P.paucimobilis が難分解性の 有機物を易分解性に変換し，ついで自然生育の混合 細菌群が分解するものと推定した。この結果， P.paucimobilis は単独で使用するより, むしろ他の 細菌との共存系で活用する方が有効であることがわ かった.

（2）微生物がすでに付着している沿岸の砂利に対 してP.paucimobilisを付着させる実験を行ったとこ ろ, 初期の付着は 3 時間以内におこった. 混合細菌 に対する付着した P.paucimobilis の割合も， P.paucimobilis が有効に働きうる範囲であった. 一 方，この砂利を海水中に浸漬して生残性を調べたと ころ,P.paucimobilis だけが剥離したり淘汰された りすることはなかった.

（3）砂利およびコンクリートを担体として，これ にP.paucimobilis を付着させて净化実験を行い, い ずれも有機物分解能が高まることを示した．砂利に おいては浄化能は 1.7 倍向上した. また, コンクリ 一トについては, 普通コンクリートに対してポーラ スコンクリートを用いれば浄化能は 2.2 倍となり, それにP.paucimobilisを付着させることによりさら に1.4倍の浄化能が得られた.

謝辞 : 本研究の一部は平成 7 年度文部省科学研究費 奨励研究(A)（代表, 伊藤禎彦) の補助を受けたこと を記し，謝意を表す．また，本研究に際し，杉本朋 哉（徳島大学大学院）, 藤井正樹（大豊建設）, 河 野通治（フジタ建設コンサルタント）の諸氏の献身 的な協力を得たことを記し，謝意を表す。

\section{参考文塥}

1) 毛利光男, 須田有輔, 上原功, 門倉伸行, 田中裕作, 細川恭史: 污濁海水浄化に扔ける碟間接触水路内の抑 留物の分布と閉塞について, 水環境学会誌, Vol.16, No.7, pp.516-525, 1993.

2 ) 門倉伸行, 西原潔, 丹羽千明, 細川恭史: 喽間接触酸 化法による海水浄化の設計諸元について, 土木学会第
48 回年次学術講演会講演概要集, pp.1028-1029, 1993.

3 ) 小田一紀, 貫上佳則, 重松孝昌, 大屋博史, 綱潔之, 倉田克彦: 磷間生物膜の海水浄化効果と現地へのその 応用に関する研究, 海岸工学論文集, 第 39 巻 (2), pp.991-995, 1992.

4 ) 服部明彦: 海洋学講座 第 7 巻 海洋生化学, 東京大学 出版会, pp.141.173, 1982.

5 ) 伊藤禎彦, 村上仁士, 細井由彦, 板東広之: 同化可能 有機炭素 (AOC) 測定による環境水の生物分解性の 推定, 第 45 回土木学会中国四国支部研究発表会講演 概要集, pp.110·111, 1993.

6 ）伊藤禎彦, 村上仁士, 細井由彦, 板東広之: 海水中難 分解性有機物の分解微生物の探索に関する研究, 海岸 工学論文集，第 40 巻（2），pp.1056-1060， 1993.

7 ) 深見公雄：有機懸濁物を住み場所とする海洋細菌群 ; 日本微生物生態学会編, 微生物の生態 16 , 学会出版 センター, pp.7-25, 1988.

8 ) 清水潮：海産魚類㧍よびプランクトンの微生物相; 日 本微生物生態学会編, 微生物の生態 2 , 学会出版セン ター, pp.71-86, 1975.

9 ) 伊藤禎彦, 村上仁士, 細井由彦, 板東広之, 落合道和 : 海水中有機物に対する効率的分解菌の活用方法に関 する研究, 海岸工学論文集, 第 41 巻 (2), pp.1076-1080, 1994.

10）伊藤禎彦, 村上仁士, 落合道和, 杉本朋哉：海水浄化 細菌の担体付着特性と水環境中における生残性, 海岸 工学論文集, 第 42 巻（2）, pp.1211-1215， 1995.

11）長谷川武治: 微生物の分類と同定（下）, 学会出版七 ンター, pp.133-134, 1975.

12）西篠八束, 奥田節夫編: 河川感潮域, 名古屋大学出版 会, 1996.

13）河合章：内湾水域における底質の有機污濁と浄化, 海洋科学, Vol.20, No.2, pp.117-123, 1988.

14) van der Kooij, D., Visser,A., and Hijnen, W.A.M.: Determining the Concentration of Easily Assimilable Organic Carbon in Drinking Water, J. of Am. Wat. Wks.Ass.,Vol.74,pp.540-545,1982.

15）村上仁士，伊藤禎彦，水口裕之，上月康則，杉本朋哉, 豊田裕作: 海水浄化実験プラントにおける浄化能の定 量化と有効菌の添加効果, 環境工学研究論文集, Vol.33, pp.367-375, 1996.

16) G.A.McFeters 編，金子光美監訳: 飲料水の微生物学, 技報堂出版, pp.67.68, 1992.

17) Ogura,N.:Further Studies on Decomposition of Dissolved Organic Matter in Coastal Seawater, Marine Biology, Vol.31,pp.101-111,1975.

18）落合道和：海水の直接浄化に寄与する細菌の浄化機構 とその工学的活用法に関する研究, 徳島大学修士論文, 


\section{MECHANISM OF DEGRADATION OF ORGANIC MATTER IN SEAWATER BY EFFECTIVE MICROBES AND ITS UTILIZATION}

\section{Hitoshi MURAKAMI,Sadahiko ITOH,Hiroyuki MIZUKUCHI,Yasunori KOZUKI and Michikazu OCHIAI}

A new biological method to improve the quality of enclosed seawater was investigated. First, degradation mechanism of Pseudomonas paucimobilis which can degrade refractory organic matter in seawater was examined. P.paucimobilis mixed with naturally grown microbes degraded organic matter 2 to 3 times as much as P.paucimobilis did by itself. After P.paucimobilis changes refractory organic matter to easily utilizable one, natural microbes can degrade the easily utilizable organic matter. P.paucimobilis was easily attached to gravels and survived in the environmental seawater. In addition, gravels and concrete to which P.paucimobilis had attached could degrade more organic matter. 